\title{
Article \\ Solar Energy Assisted Membrane Reactor for Hydrogen Production
}

\author{
Barbara Morico ${ }^{1}$, Annarita Salladini ${ }^{1}$, Emma Palo ${ }^{2}$ and Gaetano Iaquaniello ${ }^{2, *}$ \\ 1 Processi Innovativi srl, Via di Vannina 88, 00156 Rome, Italy; morico.b@processiinnovativi.it (B.M.); \\ salladini.a@processiinnovativi.it (A.S.) \\ 2 KT-Kinetics Technology S.p.A., Viale Castello della Magliana 27, 00148 Rome, Italy; e.palo@kt-met.it \\ * Correspondence: g.iaquaniello@kt-met.it; Tel.: +39-06-60216231
}

Received: 9 November 2018; Accepted: 2 January 2019; Published: 15 January 2019

\begin{abstract}
Pd-based membrane reactors are strongly recognized as an effective way to boost $\mathrm{H}_{2}$ yield and natural gas (NG) conversion at low temperatures, compared to conventional steam reforming plants for hydrogen production, thereby representing a potential solution to reduce the energy penalty of such a process, while keeping the lower $\mathrm{CO}_{2}$ emissions. On the other hand, the exploitation of solar energy coupled with a membrane steam reformer can further reduce the environmental impact of these systems. On this basis, the paper deals with the design activities and experimentation carried out at a pilot level in an integrated prototype where structured catalysts and Pd-based membranes are arranged together and thermally supported by solar-heated molten salts for steam reforming reaction
\end{abstract}

Keywords: membrane reactor; Pd-based membrane; hydrogen; steam reforming; solar energy

\section{Introduction}

Pd-based membrane reactors are strongly recognized as an effective way to boost $\mathrm{H}_{2}$ yield and natural gas (NG) conversion at low temperatures, compared to conventional steam reforming plants for hydrogen production [1-5].

Indeed, the $\mathrm{NG}$ steam reforming $\left(\mathrm{CH}_{4}+\mathrm{H}_{2} \mathrm{O}=\mathrm{CO}+3 \mathrm{H}_{2}\right)$ is an endothermic reaction $\left(\Delta \mathrm{H}^{0}{ }_{298 \mathrm{~K}}=206 \mathrm{~kJ} / \mathrm{mol}\right)$ and is limited by chemical equilibrium. This means that operation at high temperatures (850-900 ${ }^{\circ} \mathrm{C}$ ) are required to reach significant hydrogen yields. In order to supply the reaction heat duty, a stream of NG is typically burned in the steam reforming furnace, thereby determining a reduction of the overall process efficiency as well as an increase in $\mathrm{CO}_{2}$ emissions.

Under such a scenario, the coupling of the steam reforming unit with a Pd-based hydrogen-selective membrane can provide for the following benefits: (i) enhancement of hydrogen yield and process efficiency at low temperatures, since the continuous selective removal of hydrogen from reaction environment allows maintaining the gas mixture composition far from equilibrium one; (ii) replacement of the high-temperature flue gases used in the furnace with a cleaner energy source or with waste heat available from another process; (iii) use of cheaper steel alloys for the fabrication of the reforming tube instead of the expensive materials currently used to withstand the high operating temperatures of conventional steam reforming plants.

KT-Kinetics Technology has gained an impressive experience over the last 15 years in the design and operation of innovative pilot plants, membrane reformers-based, for the production of pure hydrogen [6-11]. In particular, a pilot unit of $20 \mathrm{Nm}^{3} / \mathrm{h}$ of pure hydrogen has been designed and tested for more than $3000 \mathrm{~h}$ in a relevant industrial environment with NG supplied from the town grid, with a basic configuration characterized by sequential steps of reaction and membrane separation, in order to achieve the overcoming of thermodynamic equilibrium, while maintaining at the same time slightly decoupled operating conditions for a reformer and a membrane module, thereby avoiding a 
great deal of thermal stress for Pd-based membranes. The former proposed configuration, even not totally in line with the process intensification concept, represents a more simplified membrane reactor concept, where the membrane reactor in principle does not suffer from engineering design challenges and accordingly might boost the industrial acceptance of the novel technology in the first phases of transition to it.

Over the last few years, with the aim to further reduce the $\mathrm{CO}_{2}$ emissions, typical of the highly energy-intensive processes of the hydrocarbon industry, attention has been focused by the Company on the application of solar energy as a renewable energy source, with the possibility to exploit it with molten salts having the role of heating medium and energy vector. The integration between the solar plant and industrial processes is widely studied all over the world [12-15]. For instance, Concentrating Solar Power (CSP) offers an attractive option to power industrial-scale desalination plants requiring thermal and electrical energy. Integration of CSP with multi-effect distillation (MED) and Reverse Osmosis (RO) seems to be cheaper than photovoltaic (PV) systems [16]. Another potential application of solar energy is to power chemical processes when a high thermal duty is required: this is the case for endothermic reactions, which are a very promising opportunity for the production and storage of usable energy, and mitigation of $\mathrm{CO}_{2}$ emissions.

Therefore, the aim of this paper is to report the experimental activities performed by the KT-Kinetics Technology-controlled company Processi Innovativi in the framework of the EU Project CoMETHy (Compact Multifuel Energy To Hydrogen conversion) in this field, studying the coupling of an integrated membrane reformer with solar-assisted molten salts heating, with the operation of a pilot unit specifically designed to this aim. The main feature of such a reactor is the complete integration of catalyst and membranes in only one vessel according to the process intensification concepts [17].

An economic analysis has been also carried out, in order to check the industrial feasibility of the option to provide for a competitive novel technology at reduced environmental impact.

\section{Experimental: Pilot Plant Description}

The pilot plant was designed for a capacity of $3 \mathrm{Nm}^{3} / \mathrm{h}$ of pure hydrogen. The facility is available at ENEA Casaccia premises, and the process scheme of the pilot unit is reported in Figure 1.

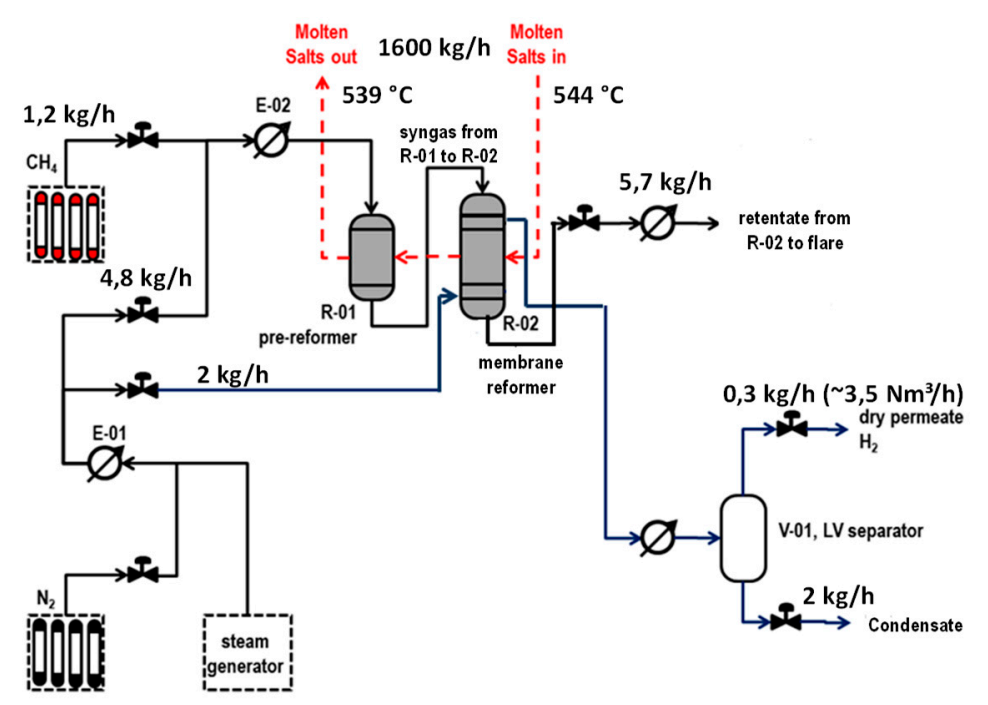

Figure 1. Solar energy-assisted membrane pilot plant process scheme.

The plant architecture is based on a first prereformer stage (R-01) placed upstream to an integrated membrane reactor (R-02). Methane is supplied by pressurized gas cylinders. A process steam and a sweep steam for membranes are produced with a dedicated electrical boiler. Reaction heat to R-01 and R-02 is supplied through a molten salts mixture fed to R-02 at a maximum inlet temperature of $550{ }^{\circ} \mathrm{C}$ and further routed to the R-01. 
Molten salts are countercurrently flowing through the two reactors, entering first R-02 at the desired temperature and flow rate. Molten salts are stored in a tank and pumped at the desired flow rate through an electrical heater, where the desired temperature is applied before being sent to the chemical test section. Due to the relatively low thermal duty of the reactors, the molten salts return temperature from the test section was just about $10^{\circ} \mathrm{C}$ lower than the molten salts supply temperature. For this reason, in order to maintain a temperature lower than $500{ }^{\circ} \mathrm{C}$ inside the molten salts tank, a fraction of the heat from the back stream was recovered by heating the molten salts stream from the tank, and finally the temperature was further reduced by means of an air cooler.

In the prereformer stage of R-01, a partial methane conversion occurs, and accordingly the produced syngas mixed with unconverted methane routed to R-02 contains a certain amount of hydrogen, allowing membrane in R-02 to be active just at the inlet of reactor.

R-01 was designed in a shell and tube configuration where molten salts mixture flows in the shell side supplying reaction heat, and catalysts are installed inside tubes (Figure 2).
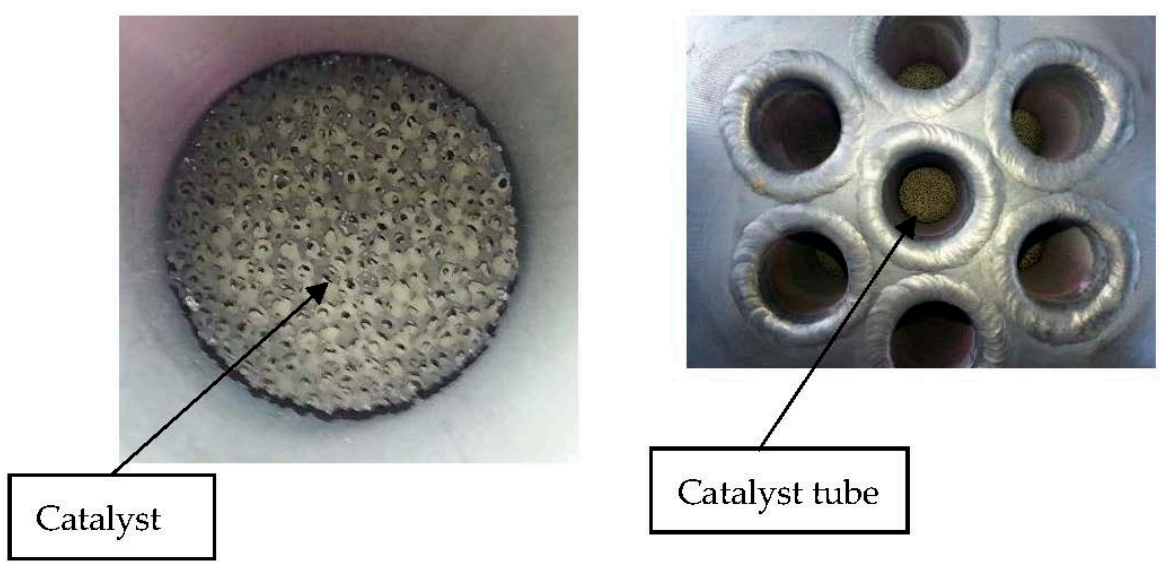

Figure 2. Catalyst arrangement in R-01 reactor.

R-02 was also designed in a shell and tube configuration (Figure 3).

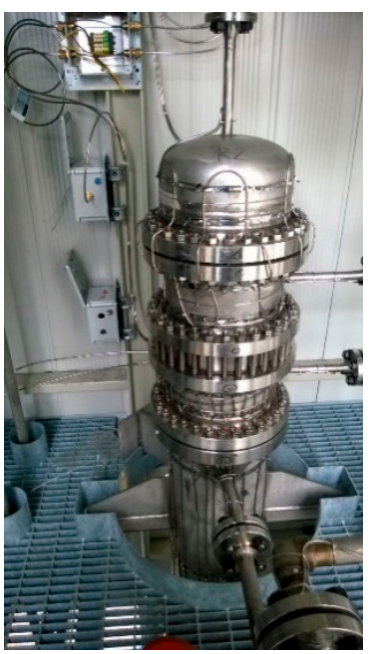

(a)

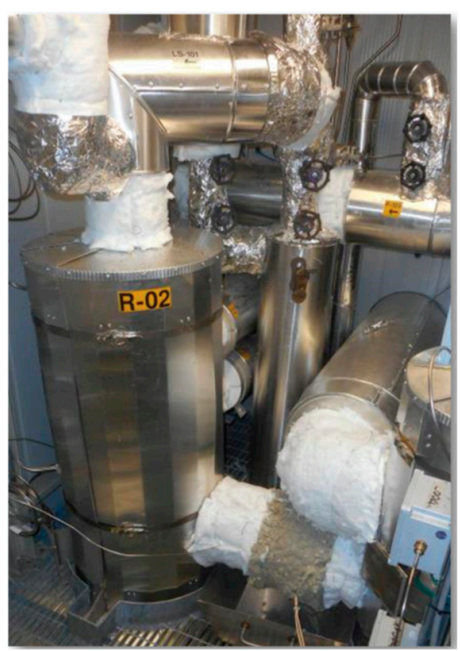

(b)

Figure 3. R-02 reactor. (a) overall reactor; (b) reactor installation.

The main difference with the R-01 reactor is that in particular in R-02, catalysts and membranes are arranged according to a tube-in-tube configuration with catalysts in the annular section around the membrane tube (Figure 4). The latter is equipped with an inner tube to allow for sweep gas flow on the permeate side. 

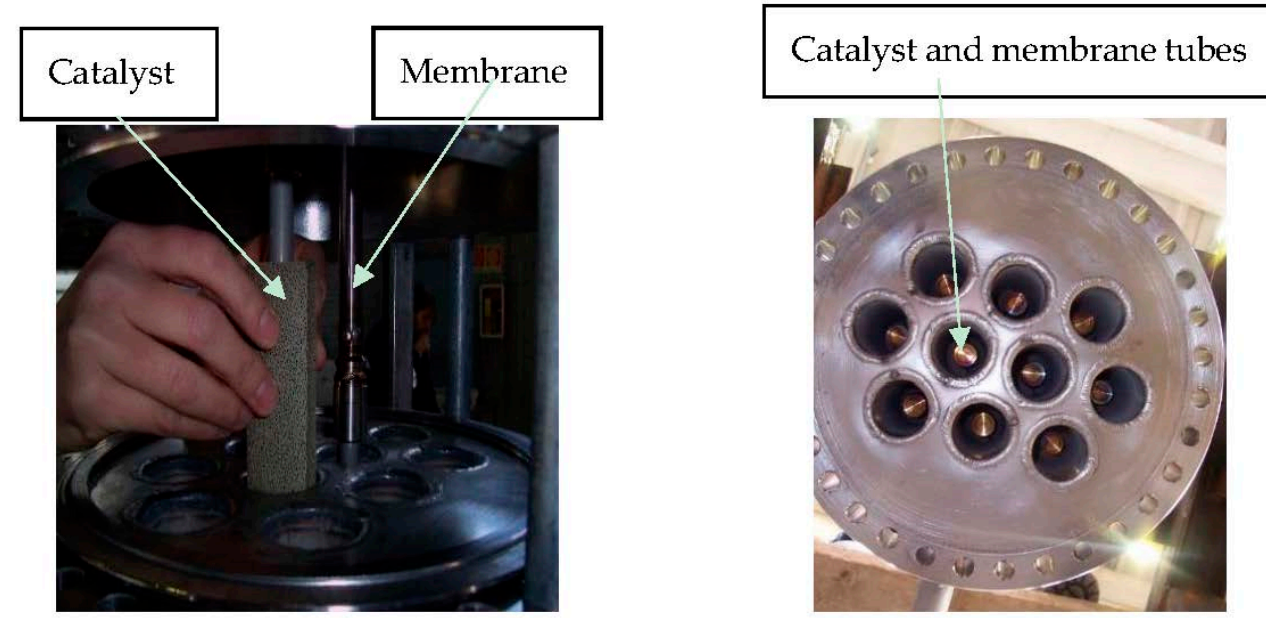

Figure 4. R-02 reactor membrane arrangement.

Ten Pd-based membrane tubes are installed in R-02, with a permeate stream collected from R-02 and cooled down in order to easily separate sweep gas as condensate.

The installed membranes were provided by ECN (Energy Research Centre of the Netherlands) and they had an outside diameter of $14 \mathrm{~mm}$ and a length of $80 \mathrm{~cm}$ for an overall area of about $0.35 \mathrm{~m}^{2}$. The main characteristics of the membranes are reported in Table 1.

Table 1. Main characteristics of membranes installed in R-02.

\begin{tabular}{|c|c|c|c|c|c|c|c|c|}
\hline Membrane & Supplier & Support & $\begin{array}{l}\text { Membr. } \\
\text { Selective } \\
\text { Layer }\end{array}$ & $\begin{array}{l}\text { Thick. } \\
\text { Selective } \\
\text { Layer, } \mathrm{m}\end{array}$ & $\begin{array}{l}\text { Membr. } \\
\text { Area, m2 }\end{array}$ & Geometry & Production Method & $\begin{array}{c}\text { Permeance, } \\
\mathrm{Nm} 3 /(\mathrm{hm} 2 \mathrm{bar} 0.5) \\
\text { at } 400-450^{\circ} \mathrm{C}\end{array}$ \\
\hline M (R-02) & ECN & $\mathrm{Al}_{2} \mathrm{O}_{3}$ & $\mathrm{Pd}$ & $3-6$ & 0.35 & Tubular & $\begin{array}{l}\text { Electroless } \\
\text { Deposition }\end{array}$ & $10-15$ \\
\hline
\end{tabular}

A bifunctional catalyst, nickel-noble metals-based, deposited on silicon carbide foam, is installed in both R-01 and R-02 reactors separately, shaped in the form of cylinder for R-01 (Figure 2) and annular cylinder for R-02 wrapped around the membrane tube (Figure 5).

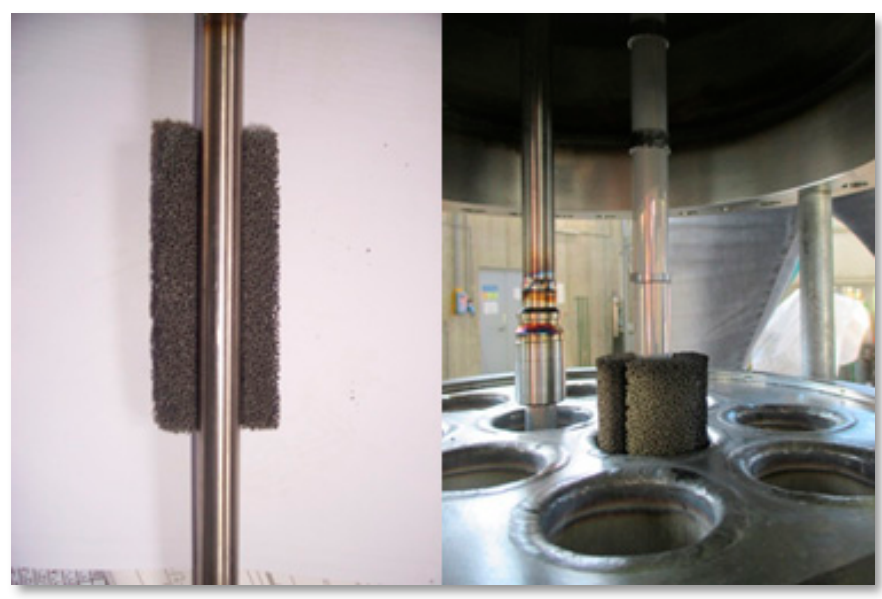

Figure 5. R-02 reactor catalyst arrangement.

The catalysts were prepared at the ProCeed Lab of the University of Salerno. To improve membrane separation efficiency, a superheated steam is used as a sweep gas in a countercurrent configuration. Reactors R-01/R-02 and piping in contact with molten salts are electrical traced, in order to assure, during the start-up and shut down procedures, temperature above the salts freezing point. 
The main operating conditions of the catalytic tests carried out with the integrated membrane reactor are reported in Table 2.

Table 2. Main operating conditions for the integrated membrane reactor.

\begin{tabular}{cc}
\hline Description & Value \\
\hline Flow rate & \\
$\mathrm{CH}_{4}$ inlet pre-reforming reactor $\mathrm{R}-01, \mathrm{~kg} / \mathrm{h}$ & $0.3-1.5$ \\
$\mathrm{H}_{2} \mathrm{O}$ inlet pre-reforming reactor $\mathrm{R}-01, \mathrm{~kg} / \mathrm{h}$ & $4.5-6.0$ \\
$\mathrm{H}_{2} \mathrm{O}$ Sweep gas, $\mathrm{kg} / \mathrm{h}$ & $0-2.0$ \\
Molten salts, $\mathrm{kg} / \mathrm{h}$ & $1250-1650$ \\
\hline Pressure & \\
P feed side, barg & $9.8-9.5$ \\
$\mathrm{P}$ permeate side, barg & 0.4 \\
\hline Temperature & \\
T range molten salts, ${ }^{\circ} \mathrm{C}$ & $450-550$ \\
\hline
\end{tabular}

For the calculation of heat and material balances of the pilot plant, each of these units was modeled with Aspen Plus 9.0 as a standard process simulator. For the integrated membrane reactor simulation, ASPEN Plus 9.0 was combined with the kinetic equations reported by $\mathrm{Xu}$ and Froment [18] and membrane permeation derived on Pd membranes coming from the same supplier and tested by the authors in the framework of previous experimental activities.

\section{Results and Discussion}

Different parameters were considered for the performance evaluation of the integrated system, such as the molten salts temperature, sweep steam flow rate and steam-to-carbon ratio. The effects of molten salts temperature on the methane conversion and the permeate $\mathrm{H}_{2}$ flow rate at an operating pressure of 8.5 barg are reported in Figure 6.

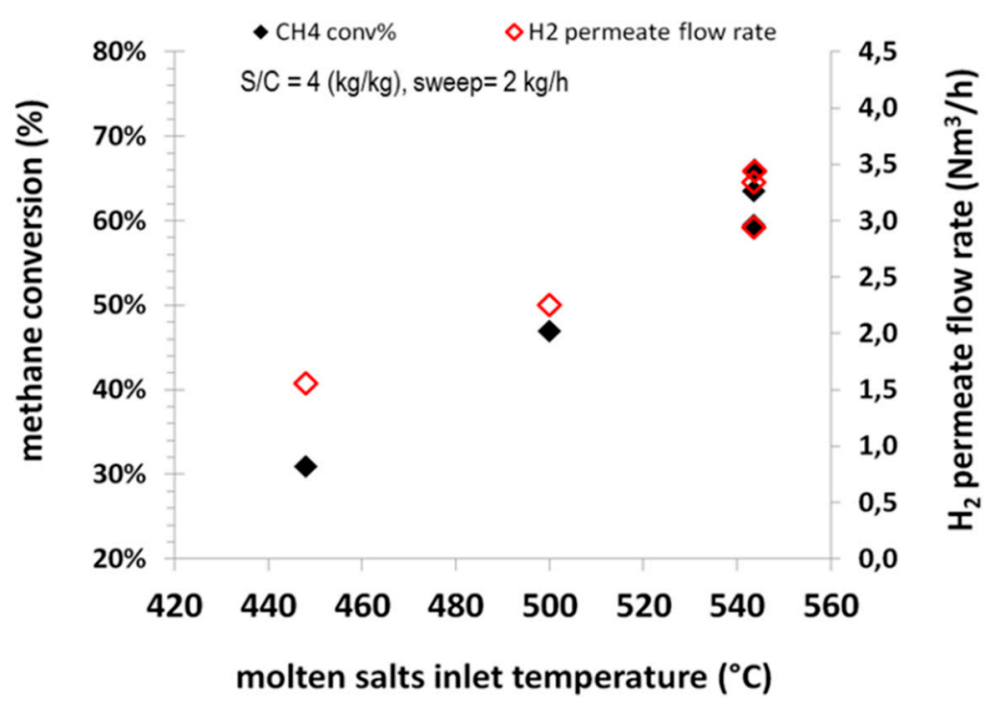

Figure 6. Effects of molten salts temperature on the methane conversion and the permeate $\mathrm{H}_{2}$ flow rate.

It can be observed that by increasing the molten salts temperature, the methane conversion increases since the endothermic reforming reaction is promoted at high temperatures, with $\mathrm{CH}_{4}$ conversion increasing from around $30 \%$ at $450{ }^{\circ} \mathrm{C}$ to around $60 \%$ at $540{ }^{\circ} \mathrm{C}$. Obviously, the same trend can be observed for the flow rate of hydrogen permeating through the Pd membranes. At $540{ }^{\circ} \mathrm{C}$, a permeate hydrogen flow rate of around $3.5 \mathrm{Nm}^{3} / \mathrm{h}$ of hydrogen can be observed. It is also of interest the low $\mathrm{CO}$ concentration can be detected on the permeate side. Such values in consequence of the low 
level in the retentate side are in order of $12 \mathrm{ppmv}$ (dry basis) at $450{ }^{\circ} \mathrm{C}$ and about $50 \mathrm{ppmv}$ (dry basis) at $540{ }^{\circ} \mathrm{C}$. The increase of $\mathrm{CO}$ concentration on the permeate side is in line with the occurrence of water gas shift more promoted at lower temperatures, thereby reducing the $\mathrm{CO}$ content on the retentate side and accordingly the $\mathrm{CO}$ detected on the permeate side. In terms of permeate purity, all tests accounted for an average $\mathrm{H}_{2}$ content higher than $99.8 \%$ mol (dry basis).

The effects of the sweep gas flow rate on the methane conversion and the permeate $\mathrm{H}_{2}$ flow rate are reported in Figure 7 for two operating temperatures, $544{ }^{\circ} \mathrm{C}$ and $500{ }^{\circ} \mathrm{C}$, respectively, at an operating pressure of $8.5 \mathrm{barg}$.

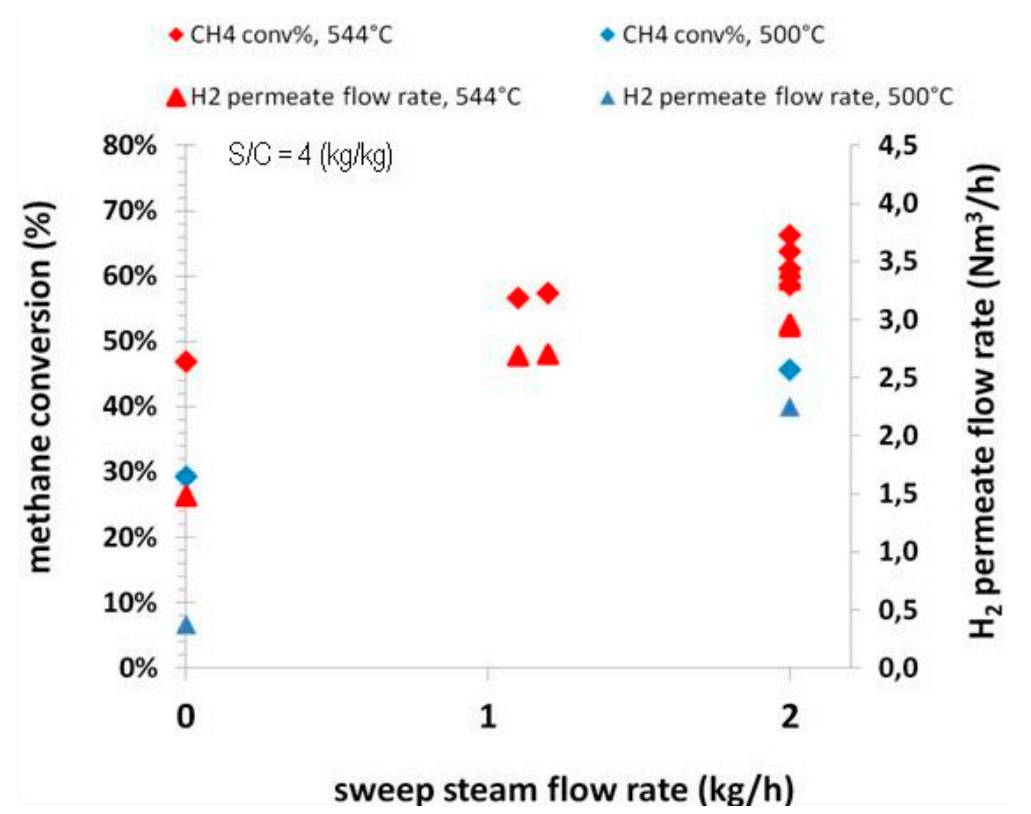

Figure 7. Effects of sweep gas flow rate on the methane conversion and the permeate $\mathrm{H}_{2}$ flow rate.

For both operating temperatures, an increase in methane conversion and accordingly in the permeate $\mathrm{H}_{2}$ flow rate can be observed with increasing of the sweep gas flow rate, since a higher value for the latter parameter enables a higher driving force across the membrane. However, it is important to observe that the strongest effect can be checked when the sweep gas flow rate is increased up to $1 \mathrm{~kg} / \mathrm{h}$. At higher flow rates, the impact is more negligible. At about $1 \mathrm{~kg} / \mathrm{h}$ of sweep gas flow rate, the hydrogen recovery is around $70 \%$ at $544^{\circ} \mathrm{C}$. A productivity of $\mathrm{H}_{2}$ of $1.5 \mathrm{Nm}^{3} / \mathrm{h}$ can be obtained, even in absence of sweep gas on the permeate side.

The effects of steam-to-carbon ratio on methane conversion and $\mathrm{H}_{2}$ recovery are reported in Figure 8 , at the three operating temperatures of $500{ }^{\circ} \mathrm{C}, 530{ }^{\circ} \mathrm{C}, 544{ }^{\circ} \mathrm{C}$ and an operating pressure of 8.5 barg. The sweep gas flow rate was kept constant at $2 \mathrm{~kg} / \mathrm{h}$.

An increase in methane conversion can be observed with increasing of the steam-to-carbon ratio in the feed. The effect is more pronounced at low temperatures. At the highest steam-to-carbon ratio investigated of 16 (on weight basis), a methane conversion of $99 \%$ can be detected at $544{ }^{\circ} \mathrm{C}$. In terms of hydrogen recovery, in this condition, it is possible to achieve a recovery of more than $90 \%$.

The performance comparison of the integrated membrane system with the thermodynamic equilibrium without a membrane is reported in Figure 9, at a feed pressure of 8.5 barg and a steam-to-carbon ratio of 4 (on weight basis). 


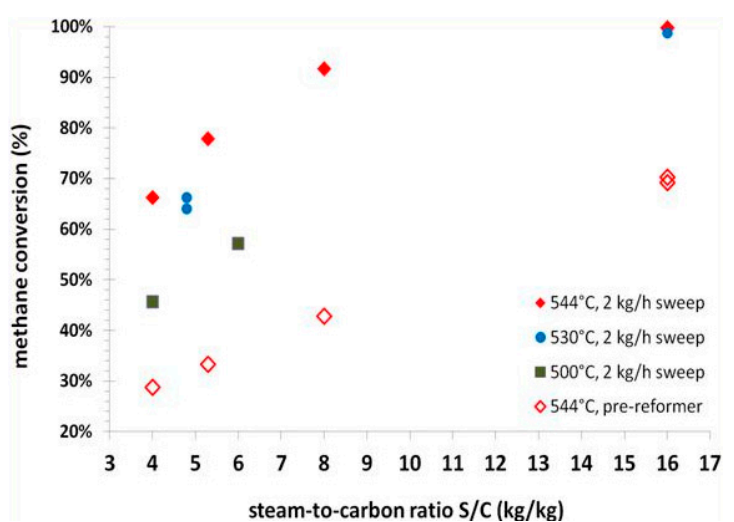

(a)

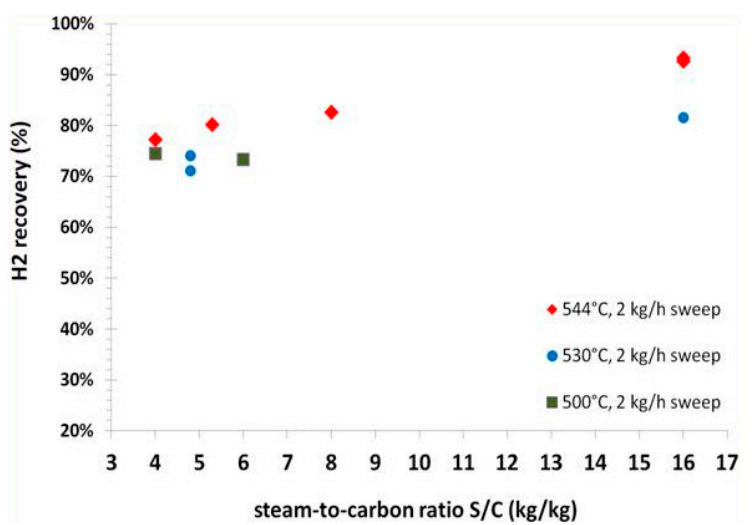

(b)

Figure 8. Effects of steam-to-carbon ratio on methane conversion (a) and $\mathrm{H}_{2}$ recovery (b).

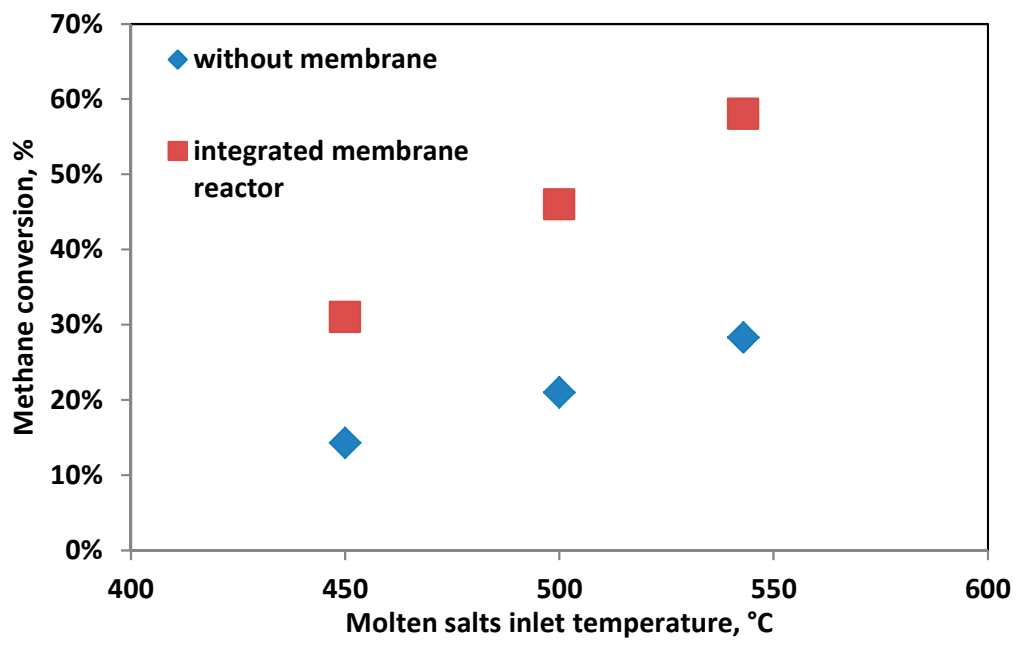

Figure 9. Methane conversion with an integrated membrane reactor and without a membrane.

An overall feed conversion of $58 \%$ can be achieved at $543{ }^{\circ} \mathrm{C}$, doubling the conversion that can be achieved in a conventional reformer at the same temperature.

The system performance was also investigated in time-on-stream tests, in order to check its potential feasibility at industrial conditions. The results in terms of the methane conversion and the permeate hydrogen concentration are reported in Figure 10.

The system performance is very stable for more than $100 \mathrm{~h}$ of continuous operation and no macroscopical signs of reactor performance loss have been evidenced over the experimental operation period, despite handling of catalysts and membranes and the several switches of operative conditions. The achieved results confirm the potentiality of the solution for application at industrial conditions; even if this concept is further assessed, it would be important to check the behavior of the membrane-catalyst coupling for at least $1000 \mathrm{~h}$ of continuous operation. Indeed, this order of magnitude of stability time is usually required for the catalyst at an accepted industrial level. In this way, if the stability of the membrane and that of catalyst are aligned to such order of magnitude, this allows to avoid too many frequent shut down operations of the plant for any procedure of maintenance or replacement of key components. 


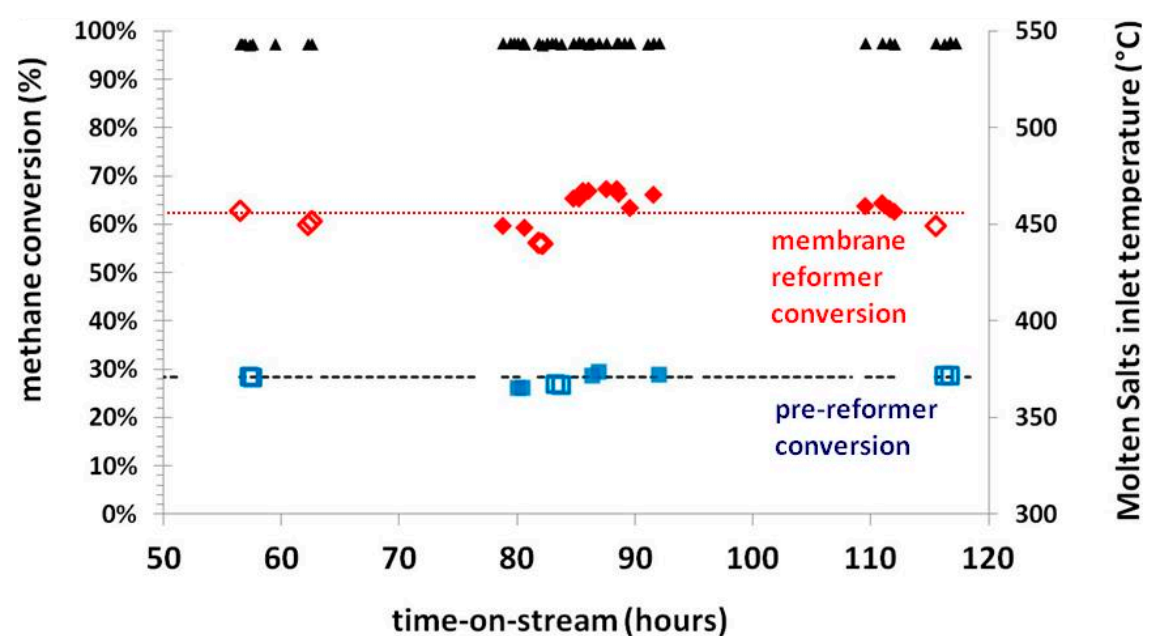

- R-02, S/C=4 (kg/kg), $2 \mathrm{~kg} / \mathrm{h}$ sweep

- $\mathrm{R}-01, \mathrm{~S} / \mathrm{C}=4(\mathrm{~kg} / \mathrm{kg}), 2 \mathrm{~kg} / \mathrm{h}$ sweep

----thermodynamic equilibrium @ $544^{\circ} \mathrm{C}$
$\Delta \mathrm{R}-02, \mathrm{~S} / \mathrm{C}=4 \mathrm{~kg} / \mathrm{kg}), 1.0-1.5 \mathrm{~kg} / \mathrm{h}$ sweep ㅁ $\mathrm{R}-01, \mathrm{~S} / \mathrm{C}=4 \mathrm{~kg} / \mathrm{kg}), 1.0-1,5 \mathrm{~kg} / \mathrm{h}$ sweep

- MS inlet temperature

(a)

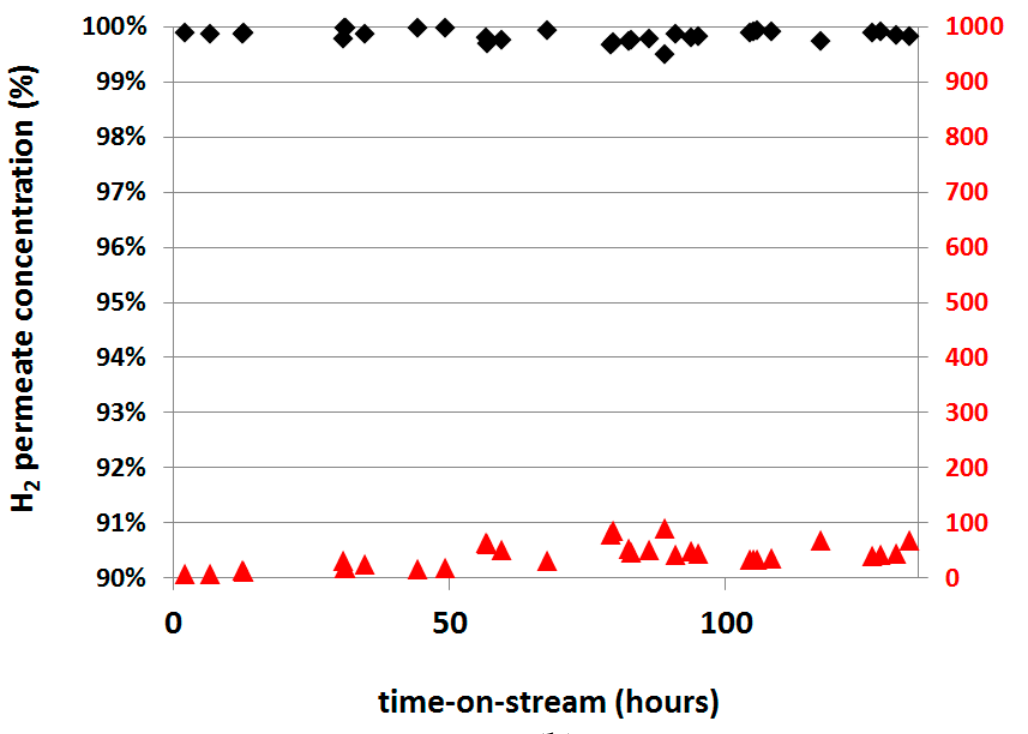

(b)

Figure 10. Methane conversion (a) and permeate $\mathrm{H}_{2}$ concentration (b) in time-on-stream tests.

\section{Economic Analysis}

In order to make a preliminary economic analysis about the potentiality of the solar energy coupling with membrane reactors at an industrial capacity of $5000 \mathrm{Nm}^{3} / \mathrm{h}$ of hydrogen, for the sake of simplicity, it was assumed to operate with a six-step membrane reactor in an open architecture, where reactions stages are followed by membrane stages.

A process arrangement has been studied in order to realize a high-energy-efficiency process coupled with a low hydrogen production cost and $\mathrm{CO}_{2}$ removal, based on the work proposed by Atsonios et al. [19]. The process scheme considered with $\mathrm{CO}_{2}$ capture in pre-combustion is reported in Figure 11. The main units are represented by: (i) the multistep membrane steam reformer, (ii) product compression, (iii) power island. Each of these units was modeled with a standard process simulator.

The rate of hydrogen removed with a Pd/Ag membrane is described by the Hydrogen Recovery Factor (HRF), which is strongly correlated with the total installed membrane area, the pressure at the permeate side, and that at the retentate side. The pressure at the feed side was set to be equal to $9.2 \mathrm{barg}$, and meanwhile, the permeate side was kept at $0.7 \mathrm{barg}$. A low-pressure steam extracted from 
the steam cycle was used as a sweep gas to reduce hydrogen partial pressure. A sweeping steam was added in order to have an equimolar mixture of hydrogen and steam on the permeate side. The HRF (Hydrogen Recovery Factor) was kept constant in our simulation and equal to 90\% (overall).

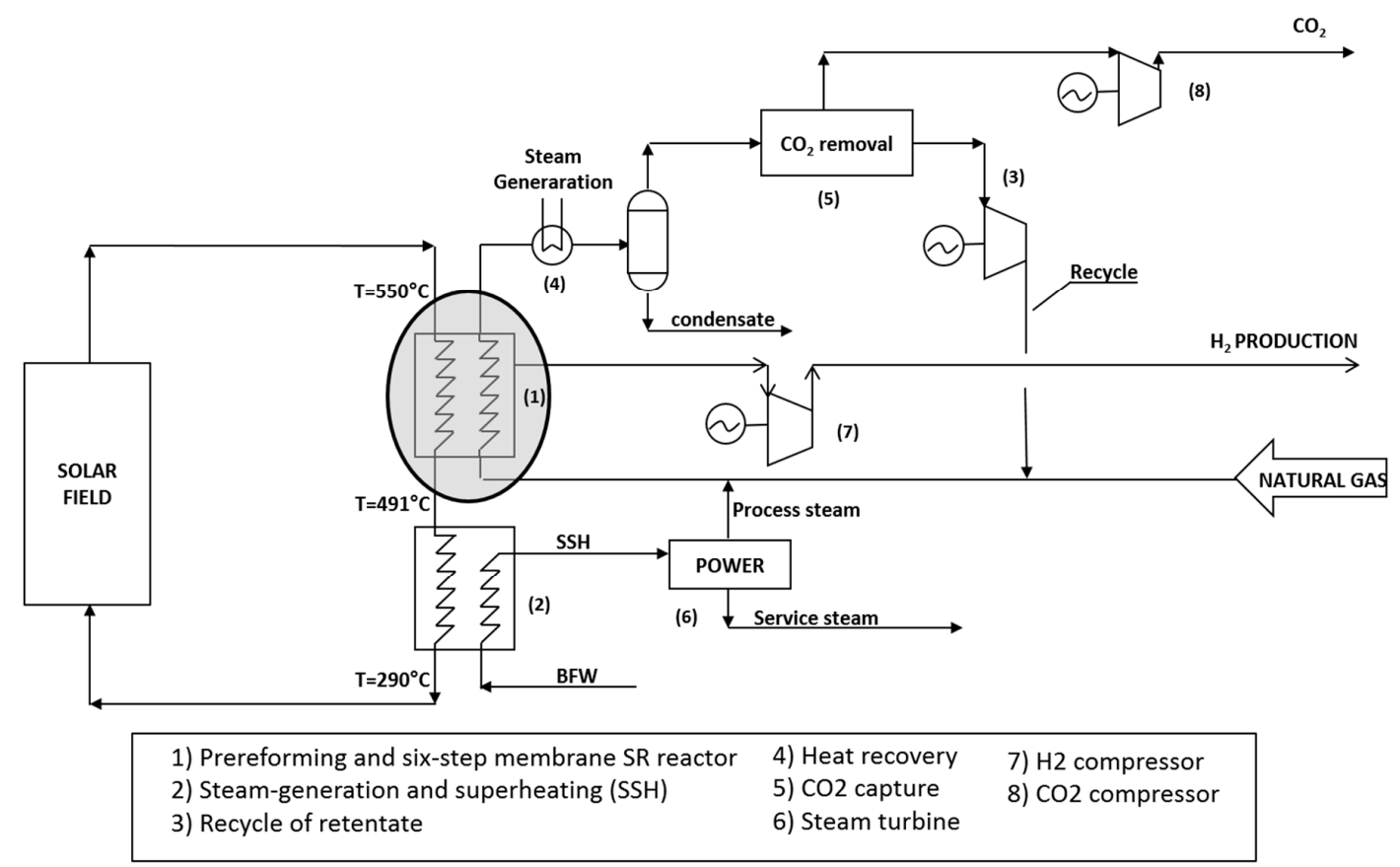

Figure 11. Process scheme for membrane steam reforming solar energy assisted with export power production.

The solar field was designed for heat molten salts with a temperature up to $550{ }^{\circ} \mathrm{C}$. Molten salts are fed to a steam reforming section composed by a pre-reformer and a six-step membrane Steam Reforming reactor. The outlet temperature of molten salts exiting the reaction section is $490^{\circ} \mathrm{C}$, so they can be used to produce the process steam required for the steam reforming reaction and the sweeping steam to be used at the membrane separation stage: additional steam is produced and used to generate power in a steam turbine.

Excess power is then exported. Molten salts are then forwarded to the solar field at a temperature of $290^{\circ} \mathrm{C}$. The NG is mixed with steam and sent to the reaction section; the produced hydrogen is recovered by membranes and then compressed to a pressure of $20 \mathrm{barg}$. The retentate is cooled down to generate steam (heat recovery) and then, after a $\mathrm{CO}_{2}$ removal stage through a conventional amine unit, compressed and recirculated to the SR section. In this way, such a scheme achieves the complete conversion of $\mathrm{NG}$ in $\mathrm{H}_{2}$ and $\mathrm{CO}_{2}$. The total duty provided by the solar field is $16.7 \mathrm{MMkcal} / \mathrm{h}$, much larger than what is required by the reforming section. The specific export of power was calculated in $0.4 \mathrm{kWh} / \mathrm{Nm}^{3}$ of produced hydrogen for an overall production of $2 \mathrm{MWh}$. The membrane area was estimated at $976 \mathrm{~m}^{2}$. In the calculation, a $5 \mu \mathrm{m}$ thick larger of $\mathrm{Pd} / \mathrm{Ag} 23 \mathrm{wt} \%$ with a permeability of $30 \mathrm{Nm}^{3} / \mathrm{h} \mathrm{m}^{2}$ bar $^{0.5}$ and $\mathrm{H}_{2} / \mathrm{CO}$ minimum selectivity of 200 was assumed [6].

The cost of production (COP) per $\mathrm{Nm}^{3}$ of $\mathrm{H}_{2}$ produced was calculated by adding the capital expenditure (CAPEX) and the operating expenditure (OPEX) costs. No benefit was taken for $\mathrm{CO}_{2}$ reduction emission. In addition, it is assumed that $\mathrm{SR}$ reactor is powered with a molten salts flow heated with solar energy for $5000 \mathrm{~h} /$ year, and in the remaining period of time, $3400 \mathrm{~h} /$ year, molten salts are heated through a process heater where NG is fired. Parameters used for economic analysis are reported in Table 3.

Table 4 reports, together with operating conditions, the relevant COP for the innovative scheme compared with a conventional steam reformer scheme, where reaction duty is provided by purge 
gas from pressure swing adsorption (PSA) and additional fuel gas. The plant architecture is that it provides the steam required by the reboiler of the $\mathrm{CO}_{2}$ recovery unit.

Table 3. Key economic parameters for the economic evaluation.

\begin{tabular}{cc}
\hline Description & Values \\
\hline NG cost, $€ / \mathrm{kg}$ & 0.22 \\
Electricity cost, $€ / \mathrm{kWh}$ & 0.075 \\
Annual depreciation factor & 10 \\
$\mathrm{~N}^{\circ}$ of hours powered by sun & 5000 \\
\hline
\end{tabular}

Table 4. Cost of production (COP) of $\mathrm{H}_{2}$ for the conventional scheme and molten salts-based steam reforming.

\begin{tabular}{|c|c|c|c|}
\hline \multirow{2}{*}{$\begin{array}{r}\text { Description } \\
\mathrm{H}_{2} \text { production, } \mathrm{Nm}^{3} / \mathrm{h}\end{array}$} & \multirow{2}{*}{$\frac{\text { Conventional SR }}{5000}$} & \multicolumn{2}{|c|}{ Molten Salts-Based SR } \\
\hline & & 5000 & 5000 \\
\hline $\mathrm{N}$ of hours & 8400 & 5000 & 3400 \\
\hline Feed + Fuel, ton $/ \mathrm{h}$ & 1.6 & 0.98 & 2.57 \\
\hline Reformer duty, MMkcal/h & 5.0 & 3.9 & 3.9 \\
\hline Solar field duty, MMkcal/h & - & 16.7 & - \\
\hline $\mathrm{H}_{2}$ compression at $20 \mathrm{barg}, \mathrm{kWh} / \mathrm{Nm}^{3} \mathrm{H}_{2}$ & - & Included & Included \\
\hline $\mathrm{CO}_{2}$ recovery, ton $/ \mathrm{h}$ & 2.55 & 2.55 & 2.55 \\
\hline OPEX, $€ / \mathrm{Nm}^{3} \mathrm{H}_{2}$ (calculated) & 0.077 & 0.045 & 0.115 \\
\hline CAPEX, M€ & 12.5 & 22.5 & 22.5 \\
\hline Export of power, $\mathrm{kWh} / \mathrm{Nm}^{3} \mathrm{H}_{2}$ & - & 0.4 & 0.4 \\
\hline Depreciation rate per year, M€ & 1.25 & 2.3 & 2.3 \\
\hline Depreciation rate, $\mathrm{M} € / \mathrm{Nm}^{3} \mathrm{H}_{2}$ & 0.030 & 0.054 & 0.054 \\
\hline Total production costs, $€ / \mathrm{Nm}^{3} \mathrm{H}_{2}$ & 0.106 & 0.068 & 0.138 \\
\hline Total average production cost, $€ / \mathrm{Nm}^{3} \mathrm{H}_{2}$ & 0.106 & \multicolumn{2}{|c|}{0.097} \\
\hline Total production cost comparison & 100 & \multicolumn{2}{|c|}{91} \\
\hline
\end{tabular}

It is quite evident that the innovative scheme is interesting and that the membrane assisted $\mathrm{H}_{2}$ production powered by solar energy, and coupled with $\mathrm{CO}_{2}$ removal may already compete with conventional steam reforming if electricity price is high enough.

In this regard, by increasing the electricity price, the difference in COP between the conventional scheme and the molten salts-based SR is higher at a higher electricity price. Anyway, as shown in Figure 12, the two configurations become equivalent at an electricity price much lower than current values.

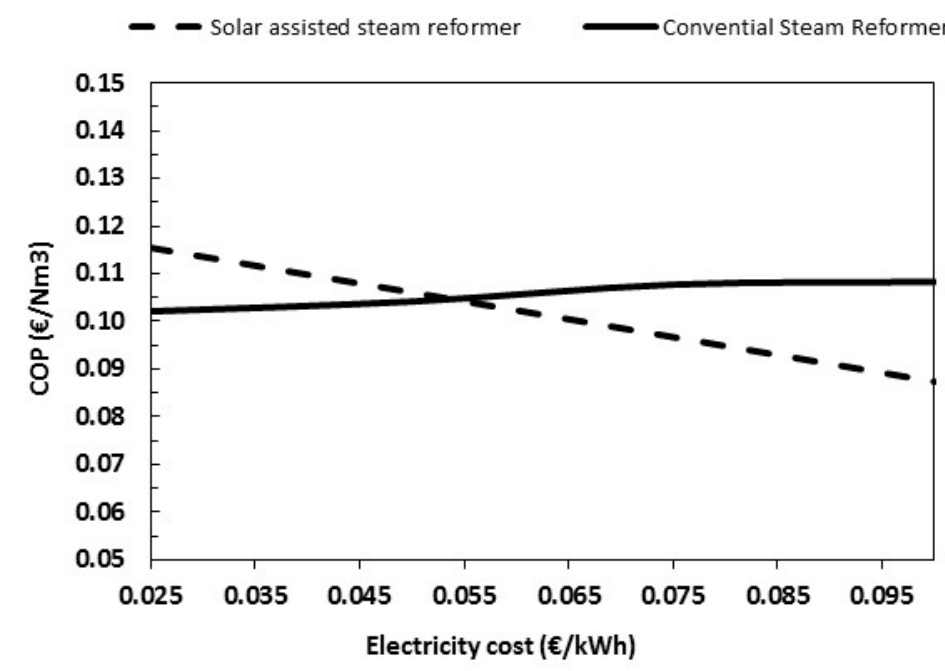

Figure 12. Influence of COP vs. electricity cost. 
It is also important to note that in conventional technology, about $70 \%$ of the production costs are related to the variable costs. The situation is quite different for the innovative scheme, where more than $55 \%$ of COP is related to the CAPEX and then only $45 \%$ is related to OPEX. Such a difference implies that, if accelerated depreciation is applied, production costs of a scheme will be more affected than for the conventional SR technology. In particular, it is calculated that the break-even point is reached at a depreciation factor of 7 ; with a depreciation factor of 12 , the difference becomes even more important, reaching almost $15 \%$.

\section{Conclusions}

The performance of a compact membrane reactor for steam reforming coupled with solar energy has been evaluated at a pilot level. The membrane reactor has been designed to integrate structured catalysts and Pd-based membranes with an overall thermal sustainment provided by solar heated molten salts. The design activities show that the engineering of a membrane reactor involves the proper optimization and arrangement of catalyst volume and membrane area. The experimentation carried out clearly indicates that the developed system is able to guarantee a high-purity hydrogen stream, keeping low feed consumption. In addition, a preliminary economic analysis, aiming at evaluating the benefits from the integration between solar energy and membrane steam reforming in open architecture, shows that the solution is a promising approach to minimizing the energy penalty, the hydrogen production cost and $\mathrm{CO}_{2}$ emitted per ton of product. Experimental time-on-stream tests with longer duration than the reported ones in this paper would further be helpful to definitely consider this scheme potentially applicable at an industrial level.

It is also worth mentioning that a proper design of a thermal storage as well as that of a back-up system could allow managing properly fluctuation of solar energy in order to assure continuous operation for the hydrogen plant.

\section{Patents}

Iaquaniello, G., Salladini, A., Morico, B. Method and system for the production of hydrogen. US Patent US9493350B2, 15 November 2016 (priority date 16 March 2012).

Author Contributions: All authors contributed to writing and correcting the paper.

Funding: The research leading to these results has received funding from the European Union's Seventh Framework Programme (FP7/2007-2013) for the Fuel Cells and Hydrogen Joint Technology Initiative under grant agreement number 279075 for CoMETHy project.

Conflicts of Interest: The authors declare no conflicts of interest.

\section{References}

1. Alique, D.; Martinez-Diaz, D.; Sanz, R.; Calles, J.A. Review of Supported Pd-Based Membranes Preparation by Electroless Plating for Ultra-Pure Hydrogen Production. Membranes 2018, 8, 5. [CrossRef] [PubMed]

2. Van Delft, Y.C.; Overbeek, J.P.; Saric, M.; de Groot, A.; Dijkstra, J.W.; Jansen, D. Towards application of palladium membrane reactors in large scale production of hydrogen. In Proceedings of the 8th World Congress on Chemical Engineering, Montreal, QC, Canada, 23-27 August 2009.

3. Basile, A. Hydrogen Production Using Pd-based Membrane Reactors for Fuel Cells. Top. Catal. 2008, 51, 107. [CrossRef]

4. Fernandez, E.; Helmi, A.; Medrano, J.A.; Coenen, K.; Arratibel, A.; Melendez, J.; de Nooijer, N.C.A.; Spallina, V.; Viviente, J.L.; Zuñiga, J.; et al. Palladium based membranes and membrane reactors for hydrogen production and purification: An overview of research activities at Tecnalia and TU/e. Int. J. Hydrog. Energy 2017, 42, 13763-13776. [CrossRef]

5. Shu, J.; Grandjean, B.P.A.; Van Neste, A.; Kaliaguine, S. Catalytic palladium-based membrane reactors: A review. Can. J. Chem. Eng. 1991, 69, 1036-1060. [CrossRef]

6. De Falco, M.; Iaquaniello, G.; Salladini, A. Experimental tests on steam reforming of natural gas in a reformer and membrane modules (RMM) plant. J. Membr. Sci. 2011, 368, 264-274. [CrossRef] 
7. De Falco, M.; Salladini, A.; Iaquaniello, G. Reformer and membrane modules (RMM) for methane conversion: Experimental assessment and perspectives of said innovative architecture. ChemSusChem 2011, 4, 1157-1165. [CrossRef] [PubMed]

8. Iaquaniello, G.; Palo, E.; Salladini, A.; Cucchiella, B. Using palladium membrane reformers for hydrogen production. In Palladium Membrane Technology for Hydrogen Production, Carbon Capture and Other Applications; Doukelis, A., Panopoulos, K., Koumanakos, A., Kakara, E., Eds.; Woodhead Publishing: Sawston, UK, 2014; pp. 287-301. ISBN 9781782422341.

9. Falco, D.M.; Iaquaniello, G.; Salladini, A. Steam reforming of natural gas in a reformer and membrane modules test plant: Plant design criteria and operating experience. In Membrane Reactors for Hydrogen Production Processes; De Falco, M., Marrelli, L., Iaquaniello, G., Eds.; Springer: Berlin, Germany, 2011; pp. 201-224. ISBN 978-0-85729-150-9.

10. Iaquaniello, G.; Palo, E.; Salladini, A. Application of membrane reactors: An industrial perspective. In Proceedings of the MR4PI2017, Villafrance de Verona, Italy, 9-10 March 2017.

11. Salladini, A.; Iaquaniello, G.; Palo, E. Membrane Reforming Pilot Testing: KT Experiences. In Membrane Reforming Pilot Testing: Applications for a Greener Process Industry; Wiley: Hoboken, NJ, USA, 2016; ISBN 978-1-118-90680-4.

12. Valenzuela, C.; Mata-Torres, C.; Cardemil, J.M.; Escobar, R.A. CSP + PV hybrid solar plants for power and water cogeneration in northern Chile. Sol. Energy 2017, 157, 713-726. [CrossRef]

13. Leiva-Illanes, R.; Escobar, R.; Cardemil, J.M.; Alarcón-Padilla, D.C.; Uche, J.; Martínez, A. Exergy cost assessment of CSP driven multi-generation schemes: Integrating seawater desalination, refrigeration, and process heat plants. Energy Convers. Manag. 2019, 179, 249-269. [CrossRef]

14. Islam, M.T.; Huda, N.; Abdullah, A.B.; Saidur, R. A comprehensive review of state-of-the-art concentrating solar power (CSP) technologies: Current status and research trends. Renew. Sustain. Energy Rev. 2018, 91, 987-1018. [CrossRef]

15. Boudries, R. Techno-economic study of hydrogen production using CSP technology. Int. J. Hydrog. Energy 2018, 43, 3406-3417. [CrossRef]

16. Iaquaniello, G.; Salladini, A.; Mari, A.; Mabrouk, A.A.; Fath, H.E.S. Concentrating solar power (CSP) system integrated with MED-RO hybrid desalination. Desalination 2014, 336, 121-128. [CrossRef]

17. Morico, B.; Gentile, A.; Iaquaniello, G. Molten Salt Solar Steam Reforming: Process Schemes Analysis. In Membrane Reactor Engineering Applications for a Greener Process Industry; Basile, A., De Falco, M., Centi, G., Iaquaniello, G., Eds.; Wiley: Hoboken, NJ, USA, 2016; ISBN 9781118906804.

18. $\mathrm{Xu}, \mathrm{J} . ;$ Froment, G.F. Methane steam reforming, methanation and water gas shift: I. Intrinsic kinetics. AIChE J. 1989, 35, 88-96. [CrossRef]

19. Atsonios, K.A.; Panopoulos, K.D.; Doukelis, A.F.; Koumanakos, A.K.; Morud, J.; Kakaras, E. Natural gas upgrading through hydrogen selective membranes: Application in carbon free combined cycles. Energy Procedia 2013, 37, 914-923. [CrossRef]

(c) 2019 by the authors. Licensee MDPI, Basel, Switzerland. This article is an open access article distributed under the terms and conditions of the Creative Commons Attribution (CC BY) license (http://creativecommons.org/licenses/by/4.0/). 